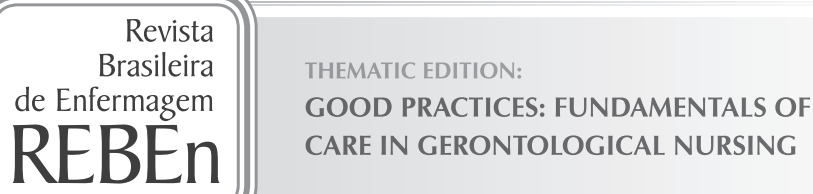

\title{
Urinary tract infection: a cohort of older people with urinary incontinence
}

\author{
Infecção do trato urinário: uma coorte de idosos com incontinência urinária
}

Infección del tracto urinario: cohorte de ancianos con incontinencia urinaria

\section{Laís Samara de Melo', Flávia Falci Ercole', Danilo Ulisses de Oliveira', Tatiana Saraiva Pinto", Mariana Avendanha Victoriano", Carla Lúcia Goulart Constant Alcoforado"I}

' Federal University of Minas Gerais, School of Nursing, Graduate Program in Nursing. Belo Horizonte, Minas Gerais, Brazil. "Federal University of Minas Gerais, School of Nursing, Undergraduate Program in Nursing. Belo Horizonte, Minas Gerais, Brazil. II' Federal University of Minas Gerais, Department of Basic Nursing. Belo Horizonte, Minas Gerais, Brazil.

How to cite this article:

Melo LS, Ercole FF, Oliveira DU, Pinto TS, Victoriano MA, Alcoforado CLGC. Urinary tract infection: a cohort of older people with urinary incontinence. Rev Bras Enferm [Internet]. 2017;70(4):838-44. [Thematic Edition "Good Practices: Fundamentals of care in Gerontological Nursing"] DOI: http://dx.doi.org/10.1590/0034-7167-2017-0141

Submission: 15-02-2017 Approval: 12-04-2017

\begin{abstract}
Objective: To evaluate epidemiological aspects of urinary tract infection in older patients with urinary incontinence living in long-term care institutions in Belo Horizonte. Method: Concurrent cohort held from April $1^{\text {st }}$ to October $1^{\text {st }}, 2015$. The study was conducted in two long-term care institutions in the city of Belo Horizonte, Minas Gerais, with 84 incontinent older people. Results: Cumulative incidence of urinary tract infection was $19 \%(95 \% \mathrm{Cl}$ : 7.83-23.19) and the incidence density was 3.6 cases/100 people-month of follow-up period. The variables Bacteriuria and Institution presented statistical association with the occurrence of urinary tract infection. Conclusion: It is observed that the incidence of urinary tract infection in the study was smaller than in other similar international and national studies, however this is an important world health problem for the older population, with impact on mortality of these individuals.
\end{abstract}

Descriptors: Urinary Infections; Urinary Incontinence; Older people; Nursing; Long-term Care Institution for the Older Population.

\section{RESUMO}

Objetivo: Avaliar aspectos epidemiológicos da infecção do trato urinário em pacientes idosos com incontinência urinária, residentes em instituições de longa permanência, de Belo Horizonte. Método: Coorte concorrente realizada no período de 01 de abril a 01 de outubro de 2015. O estudo foi realizado em duas instituições de longa permanência, na cidade de Belo Horizonte, MG, com 84 idosos incontinentes. Resultados: A incidência acumulada de infecção do trato urinário foi de $19 \%$ (IC 95\%: 7,83-23,19) e a densidade de incidência foi de 3,6 casos/100 pessoas-mês de seguimento. As variáveis Bacteriúria e Instituição apresentaram associação estatística com a ocorrência de infecção do trato urinário. Conclusão: Observa-se que a incidência de infecção do trato urinário no estudo foi menor que em outros estudos nacionais e internacionais semelhantes, no entanto trata-se de um importante problema de saúde mundial para os idosos, com impacto na mortalidade desses indivíduos. Descritores: Infecções Urinárias; Incontinência Urinária; Idoso; Enfermagem; Instituição de Longa Permanência para Idosos.

\section{RESUMEN}

Objetivo: Analizar los aspectos epidemiológicos de infección del tracto urinario en ancianos con incontinencia urinaria, en residencias para ancianos de Belo Horizonte, Brasil. Método: Se realizó una cohorte del $1^{\circ}$ de abril al $1^{\circ}$ de octubre de 2015. Se realizó el estudio en dos residencias para ancianos de la ciudad de Belo Horizonte, del cual participaron 84 ancianos con incontinencia urinaria. Resultados: La incidencia acumulada de infección en el tracto urinario fue del 19\% (IC 95\%: $7,83-23,19)$ y la densidad de la incidencia fue de 3,6 casos/100 personas-mes por seguimiento. Las variables Bacteriuria y la residencia presentaron asociación estadística en la aparición de este tipo de infección. Conclusión: A pesar de que la incidencia 
de infección del tracto urinario en este estudio fue menor que en otros estudios nacionales e internacionales de mismo tema, es un grave problema de salud para los ancianos por todo el mundo, puesto que implica la mortalidad de ellos.

Descriptores: Infección Urinaria; Incontinencia Urinaria; Anciano; Enfermería; Residencias para Ancianos.

\section{CORRESPONDING AUTHOR Flávia Falci Ercole Email: flavia.ercole@gmail.com}

\section{INTRODUCTION}

Brazil has experienced an accelerated and intense change in the age profile of the society as a result of reduction in fertility and increase in life expectancy ${ }^{(1)}$. The number of older people aged over 65 in 1970 represented $3.1 \%$ of the population. It is estimated that by 2025 , this population share will correspond to approximately $19 \%$ of the Brazilian population $^{(2)}$. In Brazil, individuals who are 60 years old or more are considered as older adults ${ }^{(3)}$.

Aging is a systemic, dynamic and progressive process, in which there are functional, morphological, biochemical and psychological changes causing reduction of ability to maintain homeostasis, leading to loss of capacity of the individuals to adapt to their environment ${ }^{(4)}$.

Accordingly, simultaneously to the population aging, the increasing occurrence of geriatric syndromes, including urinary incontinence, is observed ${ }^{(5)}$.

According to the International Continence Society (ICS), urinary incontinence is defined as a complaint of any involuntary urine loss and is a frequent condition in the general population, affecting approximately $15 \%$ to $30 \%$ of the older people living at home and at least $50 \%$ of older people in long-term care institutions ${ }^{(5)}$.

The occurrence of urinary incontinence exponentially increases with the advancement of age face to functional and structural changes in the urinary system and the impairment of functional independence ${ }^{(6)}$. However, it is worth noting: the aging process as isolated phenomenon is not the cause, but induces to anatomical and functional changes that predispose to the problem.

Studies have pointed to the presence of urinary incontinence as a risk factor for the occurrence of Urinary Tract Infections (UTI) in the older population ${ }^{(7-8)}$. However, there are few studies about the mechanisms by which that dysfunction contributes to the occurrence of UTI in older patients.

Transmission of bacteria during the incontinence care, hand hygiene and the use of absorbent devices seem to play an important role in the transmission of pathogenic microorganisms, causing UTI in incontinent people $\mathrm{e}^{(8)}$.

Urinary tract infections are the most common infections in the older people living in long-term care institutions, representing about $15 \%$ to $30 \%$ of all infections found in this population and contribute to morbidity and mortality in this age group ${ }^{(7,9)}$.

However, although it is a health problem of utmost relevance, there are few primary prospective studies published regarding the theme, and only one of them was held in Brazil ${ }^{(9)}$.

In the latest report published in 2013, ICS recognized the existence of association between urinary incontinence and UTI occurrence, after analysis of two prospective studies recently published ${ }^{(10-11)}$ and encourages the undertaking of studies that evaluate exposure (urinary incontinence) and outcome (UTI) $)^{(12-13)}$

In clinical practice, there was a high occurrence of UTI among incontinent older people interned in long-term care institutions. It should be highlighted that there is a lack of national studies evaluating the incidence and risk factors associated with UTI in this older population. Considering that nursing professionals need strong scientific evidence to support a safe and quality assistance, the necessity of studying the subject emerged.

Thus, this study aimed to evaluate the epidemiological aspects of UTI in older patients with urinary incontinence; and as specific objectives: to estimate the incidence of UTI in the studied period and to identify risk factors associated with UTI in this population.

\section{METHOD}

\section{Ethical aspects}

The project was approved by the Research Ethics Committee (COEP) according to Resolution 466/2012 of the National Health Council ${ }^{(14)}$, after authorization of the selected institutions to perform the study. An Informed Consent Form was signed by the older people who had preserved cognitive capacity or by the legal guardian before the beginning of the research.

\section{Study design, location and period}

This is a concurrent cohort of older patients with urinary incontinence, residents in two long-term care institutions of Belo Horizonte for evaluation of the development of UTI from April $1^{\text {st }}$ to October $1^{\text {st }} 2015$. The definition of follow-up period was conducted based on guidelines of the National Healthcare Safety Network ${ }^{(13)}$ that suggests a minimum follow-up of six months.

\section{Population and sample; inclusion and exclusion criteria}

To select potentially eligible participants for the research, an assessment of patients from the two institutions was carried out in order to diagnose the presence of urinary incontinence, considering the concept used by the $\mathrm{ICS}^{(7)}$, that urinary incontinence is defined as "report of any involuntary loss of urine." This evaluation was conducted by a researcher who is a Nurse Specialist in Health of the Older Population.

There were 66 older adults in Institution 1 and 72 in Institution 2, totaling 138. Hence, we conducted the measurement of incontinence volume of patients potentially eligible for the research, who used some sort of absorbent device or allowed its use. For patients who did not want to undergo the objective measurement test of urinary incontinence, a medical history was held based on the "International Consultation on Incontinence Questionnaire - Short Form" (ICIQ-SF), instrument originally developed in the English language by Avery and collaborators. This instrument was translated, adapted and 
validated in Brazil by Tamanini et al. ${ }^{(15)}$, considered appropriate for assessment of urinary incontinence in older people in the country.

After implementation and evaluation by the ICIQ-SF, 108 patients were diagnosed with urinary incontinence and they constituted the population of this study. Sample size was calculated from the population size of 108 older people and was determined from the formula described by Mingoti et al. $(2000)^{(16)}$, totaling a minimum of 82 older people.

Patients included in this study obeyed the following criteria: 60 years old or older; no use of antibiotics; no use of urethral invasive devices of long permanence; no permission or no possibility of urine collection; no hospitalization at the start of data collection; no presence of UTI at the start moment of the research. Patients who, for some reason, withdraw from the selected institutions, died or required use of invasive long permanence urinary catheters were excluded. Thus, after applying the inclusion and exclusion criteria, 84 patients participated in the follow-up and were effectively analyzed.

\section{Study protocol}

The occurrence or not of UTI was considered as dependent variable. The following independent variables were analyzed: Gender (male and female), Age (categorized according to age group, each 10 years), Institution (1 and 2), Time of stay in the institution (less than three years, three to 10 years and more than 10 years), Functionality (total dependence-Barthel index from 0 to 20; severe dependence - Barthel index from 21 to 60; moderate dependence - Barthel index from 61 to 90; and very light dependence - Barthel index from 91 to 99) as rated by Azeredo and Matos, 2003 ${ }^{(17)}$, Bacteriuria (Yes and no), Type of microorganism (classified according to the microorganism found in the urine samples), Fecal Incontinence (Yes and no), Constipation (Yes and no), Use of diapers (Yes and no), Average number of diaper change in 24 hours (lower and higher than four changes in accordance with the average, because the variable has normal distribution), Average volume of urinary incontinence in 24 hours (lower and higher than 720 $\mathrm{mL}$, according to the average, because the variable has normal distribution), and Underlying diseases (Systemic Arterial Hypertension -SHA, Diabetes Mellitus - DM, Previous Cerebrovascular Accident, Dementia, Parkinson's disease, Benign Prostate Hyperplasia, Chronic Kidney Disease).

The variables Age and Time of stay in the institution, Average volume of urinary incontinence in 24 hours and Average number of diaper changes in 24 hours were collected as continuous variables and later dichotomized.

Functionality was assessed by using the Barthel scale because it is an instrument widely used in the world for evaluation of functional independence and mobility. This scale was validated in Brazil by Minosso et al. ${ }^{(18)}$.

The average volume of urinary incontinence was established by diaper weighing before and after use, over a period of 48 hours; an average of urinary loss in 24 hours was established by dividing the value found by two. The same procedure was done in relation to the number of diaper changes, whose value found in 48 hours was divided by two.
Patients were evaluated about the signs and symptoms of UTI during the follow-up period on a daily basis. When present, urine samples were collected for analysis of laboratory culture.

The nursing staff of the two institutions participated in the daily evaluation of signs and symptoms of UTI in older patients participating in the study. For this purpose, before the start of data collection, training and case studies on evaluation of signs and symptoms of UTI in the older people were held. After this step, each nurse along with the researcher assessed 20 patients of the institution. The researcher, who is a gerontologist nurse, was considered the gold standard for evaluation of signs and symptoms of UTI in older patients participating in the research. The agreement evaluation among the evaluators was held by means of the Kappa coefficient, considering for the study the values recommended by Landis and Kock ${ }^{(19)}$ as substantial and almost perfect agreement, namely, 0.7 to 1 scores. In this study, the Kappa values ranged from 0.773 to 1.0 , therefore, all higher than 0.7 or $70 \%$.

\section{Analysis of the results and statistics}

For data descriptive analysis, simple frequency distributions, measures of central tendency (mean and median) and measures of variability (standard deviation) were used.

Cumulative incidence $(\mathrm{Cl})$ and Incidence Density (ID) of UTI were calculated in the study period, to perform comparisons with similar studies.

For the bivariate analysis between the dependent variable (UTI) and independent variables, the Chi-square test with Yates correction was used when more than $20 \%$ of the cells showed less than five observations. Mantel-Haenszel test was used to evaluate the presence of confounding variables.

In the multivariate analysis, the variables selected in the bivariate $(p<0.20)$ were placed one by one by the stepwise forward method, with control of the variable Dementia (confounding factor in the Mantel-Haenszel analysis), considering p-value lower than 0.05 and the Log Likelihood Ratio (LLR) indicating the contribution of the variable for better model adjustment.

\section{RESULTS}

We analyzed data of 84 older patients with urinary incontinence from April $1^{\text {st }}$ to October $1^{\text {st }}, 2015.77 .1$ years old was the average age of these patients. There was a balanced distribution in the participation of men and women and also in relation to the institutions to which they belonged. Average time of stay in the institutions was 5.5 years. Most older people presented a high degree of dependence, since $80.9 \%$ of patients were classified with a Barthel's index value less than or equal to 60 , which characterizes severe or total dependence.

Regarding the presence of bacteriuria, there was a considerable number of older people showing this condition $(42.9 \%)$, being Escherichia Coli the most prevalent organism $(52.8 \%)$, followed by Enterobacter ssp (25.0\%). Most patients (88.6\%) had at least one underlying disease. In addition, it is worth mentioning that all patients in the study had urinary incontinence and $76.2 \%$ had fecal incontinence. 
Table 1 - Epidemiological and health data of older patients living in two long-term care institutions of Belo Horizonte, Minas Gerais, Brazil, 2015

\begin{tabular}{|c|c|c|c|}
\hline Variable & $\mathbf{n}$ & $\%$ & Mean (SD $\ddagger)$ \\
\hline Age & & & $77.1(8.6)$ \\
\hline $60-69$ & 20 & 23.8 & \\
\hline $70-79$ & 34 & 40.5 & \\
\hline $80-89$ & 22 & 26.2 & \\
\hline 90 or older & 8 & 9.5 & \\
\hline \multicolumn{4}{|l|}{ Gender } \\
\hline Male & 44 & 52.4 & \\
\hline Female & 40 & 47.6 & \\
\hline \multicolumn{4}{|l|}{ Institution } \\
\hline 1 & 40 & 47.6 & \\
\hline 2 & 44 & 52.4 & \\
\hline \multicolumn{4}{|l|}{ Functionality } \\
\hline Total Dependence & 41 & 48.8 & \\
\hline Severe Dependence & 27 & 32.1 & \\
\hline Moderate dependence & 11 & 13.1 & \\
\hline Very Light Dependence & 5 & 6.0 & \\
\hline Time of stay in the institution (years) & & & $5.5(5.2)$ \\
\hline Less than 3 & 28 & 33.3 & \\
\hline $3-10$ & 44 & 52.4 & \\
\hline More than 10 & 12 & 14.3 & \\
\hline \multicolumn{4}{|l|}{ Bacteriuria } \\
\hline No & 48 & 57.1 & \\
\hline Yes & 36 & 42.9 & \\
\hline \multicolumn{4}{|l|}{ Constipation } \\
\hline No & 76 & 90.5 & \\
\hline Yes & 8 & 9.5 & \\
\hline \multicolumn{4}{|l|}{ Fecal Incontinence } \\
\hline No & 19 & 22.6 & \\
\hline Yes & 65 & 77.4 & \\
\hline \multicolumn{4}{|l|}{ Use of diapers } \\
\hline No & 18 & 20.2 & \\
\hline Yes & 66 & 79.8 & \\
\hline \multicolumn{4}{|l|}{ Underlying diseases } \\
\hline Escherichia Coli & 19 & 52.8 & \\
\hline Klebisiella ssp & 3 & 8.3 & \\
\hline Enterococcus Faecalis & 1 & 2.8 & \\
\hline Enterobacter ssp & 9 & 25.0 & \\
\hline Morganela Morgani & 1 & 2.8 & \\
\hline Staphylococcus ssp & 2 & 5.5 & \\
\hline Pseudomona ssp & 1 & 2.8 & \\
\hline Systemic Arterial Hypertension & 53 & 63.1 & \\
\hline Previous cerebrovascular accident & 38 & 45.2 & \\
\hline Dementia & 38 & 45.4 & \\
\hline Diabetes Mellitus & 21 & 25 & \\
\hline Chronic Kidney Disease & 2 & 2.3 & \\
\hline Parkinson's disease & 1 & 1.2 & \\
\hline Benign prostate hyperplasia & 1 & 1.2 & \\
\hline
\end{tabular}

Note: $\ddagger$ Standard Deviation.

Regarding the use of diapers, 66 patients $(79.8 \%)$ used this product. Most older people had four or more diaper changes a day $(73.8 \%)$. The average number of diaper change ranged from two to five changes per day. In relation to the incontinence volume, the majority of patients $(53.8 \%)$ had volume $<720 \mathrm{~mL} /$ day.

During the follow-up period, there were 16 new UTI cases. Thus, the $\mathrm{Cl}$ of $\mathrm{UTI}$ was $19 \%(95 \% \mathrm{Cl} 7.83-23.19)$. Whereas the ID calculated was 3.60 cases/100 people-month of followup period (95\% Cl: $1.87-5.33)$, since in the study, 16 new UTI cases were detected and 444 people/month at risk, during follow-up. In relation to the signs and symptoms of UTI, $62 \%$ of patients presented atypical symptoms (hypoactive delirium and hyperactive delirium). Fever was present in $25 \%$ of cases. Report of dysuria and suprapubic pain was found in $12.5 \%$. Only $1(6.25 \%)$ patient reported increased urinary urgency.

Table 2 - Number of diaper changes and incontinence volume of incontinent older people who use diapers, Belo Horizonte, Minas Gerais, Brazil, 2015

\begin{tabular}{lcccc}
\hline Variable & Categories & $\mathbf{n}$ & \% & Mean (SD $)$ \\
\hline $\begin{array}{l}\text { Average number of } \\
\text { diaper changes in } 24\end{array}$ & $\leq 3$ & 18 & 26.2 & $3.8(0.6)$ \\
$\begin{array}{l}\text { hours } \\
\begin{array}{l}\text { Average volume of } \\
\text { urinary incontinence in }\end{array}\end{array}$ & $<$ or more & 48 & 73.8 & \\
$\begin{array}{l}24 \text { hours } \\
\geq 720 \mathrm{~mL}\end{array}$ & 36 & 53.8 & $728.1(323)$ \\
\hline
\end{tabular}

Note: $¥$ Standard Deviation.

The bivariate analysis showed that only Bacteriuria and Institution were significantly associated to UTI. For Bacteriuria, $\mathrm{x}^{2}(1)=8.338 ; \mathrm{p}=0.004 ; \mathrm{RR}=2.588 ; \mathrm{OR}=5.50$. And for Institution $x^{2}(1)=4.054 ; p=0.044 ; R R=2.118 ; O R=3.37$. The variable Dementia showed only one tendency of association with $U T I x^{2}(1)=3.268 ; p=0.071 ; R R=0.667 ; O R=0.333$ (inverse association).

Table 3 - Result of analysis of association between independent variables and the development of Urinary Tract Infection, Belo Horizonte, Minas Gerais, Brazil, 2015

\begin{tabular}{|c|c|c|c|c|c|}
\hline \multirow{2}{*}{ Variables } & \multicolumn{2}{|c|}{ UTI‡ } & \multirow{2}{*}{ Total } & \multirow{2}{*}{$p$ value } & \multirow{2}{*}{$\begin{array}{l}95 \% \mathrm{Cl}^{*} \text { of } \\
\text { the } p \text { value }\end{array}$} \\
\hline & No & Yes & & & \\
\hline \multicolumn{6}{|l|}{ Institution } \\
\hline Institution 1 & 36 & 4 & 40 & \multirow[t]{2}{*}{0.044} & \multirow[t]{2}{*}{$0.019 ; 0.413$} \\
\hline Institution 2 & 32 & 12 & 44 & & \\
\hline \multicolumn{6}{|l|}{ Bacteriuria } \\
\hline No & 44 & 4 & 48 & \multirow[t]{2}{*}{0.004} & \multirow[t]{2}{*}{$0.130 ; 0.496$} \\
\hline Yes & 24 & 12 & 36 & & \\
\hline Dementia & 34 & 12 & 46 & \multirow{3}{*}{0.071} & \multirow{3}{*}{$-0.411 ; 0.08$} \\
\hline No & 34 & 12 & 46 & & \\
\hline Yes & 34 & 4 & 38 & & \\
\hline
\end{tabular}

Note: ₹ Urinary Tract Infection; * Confidence Interval.

To evaluate the presence of confounding factors by the Mentel-Haenszel test, only the variable dementia was identified as confounding variable.

The variables tested in the logistic regression model were the ones that had $p<0.1$ in the bivariate analysis: Institution, Bacteriuria and Dementia. In addition, Use of diapers was also included, due to the clinical importance of this variable 
described in the literature, although the p-value was higher than the cut used for inclusion in the model. It is worth remembering that the variable Dementia was controlled in the analysis for being identified as a confounding factor.

In the model used, the only variable that was statistically significant was Bacteriuria $(p=0.007$; $\mathrm{Cl} 1.598-18.931$; OR: 5.500. The variable Institution presented only one tendency of association $(P=0.068)$.

\section{DISCUSSION}

From the results presented, it was possible to notice that, during the period studied, the $\mathrm{Cl}$ was $19 \%$ and the ID was 3.60 cases/100 people-month of follow-up period. In the literature review carried out for the development of this research, it was found only one prospective study that examined the incidence of UTI in older patients with incontinence ${ }^{(8)}$. In this study, the $\mathrm{CI}$ found was of $34 \%$, much higher value than found in this current research, suggesting a better quality of assistance provided to these patients in the institutions where this research was held.

However, it is worth mentioning that the study by Omli et al. ${ }^{(8)}$ lasted one year and was held in six LTC institutions for older adults in Norway, with a number of 153 patients. These older people had an average age higher than the one found in this study, and most of the sample studied was composed of women. Such factors contributed for the $\mathrm{Cl}$ in the study cited to be higher than in the institutions researched in this study.

A study on UTI on older residents at LTC institutions, held in Brazil, showed a prevalence of $23 \%$, and $50 \%$ of these patients were older people with urinary incontinence ${ }^{(9)}$.

In documents published by the CDC, the average incidence of UTI in institutionalized older patients was not found, but these documents reported that the prevalence of asymptomatic bacteriuria in LTC institutions is about $20 \%$ to $50 \%$ and that the incidence of UTI is lower, though it is a significant infection that results in using large quantities of antibiotics ${ }^{(13)}$.

In relation to the sample studied, patients aged 80 to 89 years were those who had higher occurrence of UTI (41.1\%), although the difference between the age groups was not significant. This result was also found in similar studies ${ }^{(8,20)}$.

According to the literature, the incidence of UTI increases with age in both men and women. From 85 years old on, the occurrence of UTI increases from approximately 0.05 to 0.08 people per year in men and from 0.07 to 0.13 people per year in women ${ }^{(21)}$.

When it comes to gender, there was no significant difference either. Considering that the average age of patients participating in the study is high (approximately 78 years old), this result is expected, since with the advancing age, the difference in occurrence of UTI between genders decreases ${ }^{(13)}$.

Whereas the presence of bacteriuria presented significant difference regarding the occurrence of UTI in all statistical models used, increasing the risk of occurrence of the event up to 2.6 times.

Bacteriuria, also known as asymptomatic UTI, is characterized by the presence of at least one microorganism in urine culture, collected in a catheter or not, but the individual does not shows signs and symptoms related to the urinary tract.
Prevalence in institutionalized older individuals is high, reaching $25 \%$ to $50 \%$ of women and $15 \%$ to $40 \%$ of men $^{(13)}$.

However, the bacteriuria treatment is not recommended, due to persistence of urinary tract colonization, despite the use of antibiotics and the high potential for development of resistance to these drugs ${ }^{(22)}$.

The most commonly etiologic factor found is Escherichia Coli, microorganism that is part of the normal intestine flora, as it was also identified in this study.

In the list of risk factors for the development of bacteriuria, are age and gender (more women than men), neurological diseases, in particular Alzheimer's disease, Parkinson's disease and CVA, DM, primary biliary cirrhosis, reduced mobility, constipation, use of catheters and urinary tract abnormalities such as: calculus, urinary incontinence with increased residual bladder volume and prostate enlargement ${ }^{(23)}$.

Thus, the prevention, control and treatment of chronic diseases becomes important in reducing the occurrence of bacteriuria. In this study, it was possible to observe that $91.9 \%$ of patients who presented bacteriuria had at least one of the underlying diseases researched, in addition to urinary incontinence, present in all research participants.

Regarding the functionality, there was no significant association with UTI occurrence, when categorized as recommended by the literature. This result may have been found due to the fact that most patients present total and severe dependence, and there is not a representative number of patients in moderate and very light categories.

In a similar study found, Omli et al. ${ }^{(8)}$, who also assessed the degree of dependency of older people by the Barthel Index, there was no statistical analysis of the association between this variable and the occurrence of UTI. Another study, conducted by Caljouw et al. ${ }^{(10)}$, assessed the degree of dependency through the Groningen Activity Restriction Scale, characterizing individuals as independent or dependent, when they present dependence on at least one of the 9 ADLs described by the scale. In this study, there was a significant association between dependence degree and occurrence of UTI.

In the sample studied, when evaluating patients regarding the use of diapers, it is possible to notice that most of them use this device. $87.5 \%$ of patients that presented UTI were wearing diapers. However, this result was not statistically significant, but it increased the risk of UTI up to 1.8 times (95\% Cl 0.3-9.3). The same situation occurred in relation to the incontinence volume and the average number of diaper changes per day.

Omli et al. ${ }^{(8)}$ also assessed these 3 variables, having found only the use of diapers associated with occurrence of UTI. It is believed that the sample size was insufficient to statistically demonstrate the association between use of diapers and UTI in this study.

The variable Institution presented a tendency of association with the UTI occurrence. For patients of Institution 2, the risk of having UTI found was 2.1 times higher when compared to patients who resided in Institution 1. It is observed that $75 \%$ of patients who had UTI were in Institution 2.

In this sense, some aspects may have contributed to the increased occurrence of UTI in Institution 2. We can cite the limited number of professionals involved in the direct patient care, if 
compared with Institution 1. In Institution 2, there are 39 professionals among physicians, physical therapists, occupational therapists, speech therapists, psychologists, social workers, nurses, nursing technicians and caregivers, for the care of 71 older adults. In Institution 1, the proportion is 59 professionals for 66 older adults. The difference in the number of caregivers is specially highlighted: 20 professionals in Institution 2 and 35 in Institution 1.

Quantitative aspects of professionals in the health institutions are emphasized for the guarantee of safety and quality of care provided to patients ${ }^{(24)}$. The National Health Surveillance Agency (ANVISA) ${ }^{(25)}$ determined the minimum number of professionals to work at LTC institutions according to the assistive modality offered. In this sense, the institution closest to the established by ANVISA is Institution 1.

Another important aspect is the organization of nursing care in these institutions. In Institution 1, there is an implementation movement of Systematization of Nursing Care (SNC) by means of the Nursing Process (NP). The Nursing Theory chosen by the institution is the Basic Human Needs Theory by Wanda de Aguiar Horta. The operationalization of the nursing process steps is being progressively carried out, initially prioritizing the most critical patients. The Institution 2 still does not have a systematic nursing care.

The SNC implementation is pointed as a methodology able to improve the quality of nursing care, for offering scientific support, increasing patient safety and directing the performance of activities carried out by the nursing staff ${ }^{(26-27)}$.

\section{Study limitations}

During the conduction of the study, some elements that bring difficulty and facilitators were found. As for the ones that made it difficult, we can cite the difficulty of obtaining some data on charts of patients, especially related to diagnoses of comorbidities presented by the older people. We can also cite the difficulty in daily follow-up of older people, due to the clinical profile of high cognitive and functional impairment. In addition, due to the absence of research funding, it was not possible to perform urodynamic studies. Such examination would allow to determine the types of urinary incontinence presented by older people and the association of their related factors with the occurrence of UTI, as it was not possible to identify through medical history the type of urinary incontinence, considering the profile of patients in the study.

As facilitators, we can cite knowledge of the clinic involved, proximity with the subject studied and cooperation of the institutions for this study to be conducted in the best possible way.

This study reflects the particular profile of incontinent older patients of 2 LTC facilities in Belo Horizonte, which reflects the need for multicenter studies to legitimize the external validity of the study.

Contributions to the fields of nursing, health or public policy

It is believed that this study can contribute to care in preventing the occurrence of UTI in incontinent older patients, as well as subsidizing studies which allow a greater knowledge on the subject, enabling clinical trials that contribute to a higher quality of assistance.

\section{CONCLUSION}

From the results, it is possible to verify that the incidence of UTI in the study was lower than the one found in similar studies. This may be related to the profile of patients and to the follow-up period, which was lower than in the comparative studies.

The variables that associated the UTI occurrence were Bacteriuria and institution. However, when the variable "Use of Diapers" was analyzed, it was possible to realize increased risk of UTI in these patients.

The main clinical manifestations of the patients were considered atypical: hypoactive delirium and hyperactive delirium. This result was also found in similar studies. Thus, the inclusion of such symptom among the manifestations of UTI in the older people is recommended.

Collaborative and integrated actions are necessary in order to facilitate the recognition and clinical management of UTI in incontinent older patients. Furthermore, recognizing the risk factors and consequently adopting preventive measures will certainly reduce the likelihood occurrence of UTI in these patients.

\section{REFERENCES}

1. Veras R. Envelhecimento populacional contemporâneo: demandas, desafios e inovações. Rev Saúde Pública [Internet]. 2009 [cited 2016 Mar 13];43(3):548-54. Available from: http://www.scielosp.org/pdf/rsp/v43n3/224.pdf

2. Brasil. Instituto Brasileiro de Geografia e Estatística. Sinopse dos resultados do censo 2010[Internet]. IBGE: Brasil; 2010 [cited 2015 Dec 14]. Available from: http://www.censo2010.ibge.gov.br/sinopse/webservice/.

3. Brasil. Lei n 10.741 de outubro de 2003. Dispõe sobre o estatuto do idoso e dá outras providências. [Internet]. 2003 [cited 2016 Aug 18]. Available from: http://www.planalto.gov.br/ccivil_03/leis/2003/l10.741.htm

4. Menezes RL, Bachion MM, Souza JT, Nakatani AYK. Estudo longitudinal dos aspectos multidimensionais da saúde de idosos institucionalizados. Rev Bras Geriatr Gerontol [Internet]. 2011 [cited 2016 Aug 18];14(3):485-96. Available from: http://www. scielo.br/pdf/rbgg/v14n3/v14n3a09

5. Moraes EM, Marino MCA, Santos RR. Principais Síndromes Geriátricas. Rev Med MG [Internet]. 2010 [cited 2016 Sep 02];20(1):5466. Available from: http://www.rmmg.org/artigo/detalhes/383

6. Aguilar-Navarro S, Navarrete-Reyes AP, Grados-Chavaria BH, Garcia-Lara JM, Annieva H, Avila-Funes JA. The severity of urinary incontinence decreases health-related quality of life among community-dwelling elderly. J Gerontol A Biol Sce Med Sci [Internet]. 
2012 [cited 2015 Sep 30]; 67(1):1266-71. Available from: http://biomedgerontology.oxfordjournals.org/content/67/11/1266.long

7. Abrams P, Anderson VE, Birder L, Brubaker L, Cardozo L, Chapple C, et al. Fourth International Consultation on Incontinence Recommendations of the International Scientific Committee: evaluation and treatment of urinary incontinence, pelic organ prolapse, and fecal incontinence. Neurourol Urodyn [Internet]. 2010 [cited 2015 Aug 18];29(1):213-40. Available from: http:// onlinelibrary.wiley.com/doi/10.1002/nau.20870/abstract;jsessionid = 83C7D9E794905EF48FB640AB5A8012AF.f04t04

8. Omli R, Skotnes LH, Romild U, Bakke A, Mykletun A, Kuhry E. Pad per day usage, urinary incontinence and urinary tract infections in nursing home residents. Age Ageing [Internet]. 2010 [cited 2016 Feb 14];39(5):554-9. Available from: https://ageing. oxfordjournals.org/content/39/5/549.full

9. Molinari K. Infecção do trato urinário em idosos institucionalizados [Dissertação]. São Paulo: Universidade Federal de São Paulo. Escola Paulista de Medicina; 2004.

10. Caljouw MAA, Elzen WPJ, Cools HJM, Gussekloo J. Predictive factors of urinary tract infections among the oldest old in the general population: a population-based prospective follow-up study. BMC Med [Internet]. 2011 [cited 2016 Jan 15];9(57):1-8. Available from: https://www.ncbi.nlm.nih.gov/pmc/articles/PMC3117726/pdf/1741-7015-9-57.pdf

11. Moore EE, Jackson SL, Boyko EJ, Scholes D, Fihn SD. Urinary incontinence and urinary tract infection: temporal relationships in postmenopausal women. Obstet Gynecol. [Internet]. 2008 [cited 2016 Jan 15];111(2 Pt 1):317-23. Available from: https://www. ncbi.nlm.nih.gov/pubmed/18238968

12. Abrams P, Cardozo L, Khoury S, Wein A. Incontinence. International Consultation on Incontinence [Internet]. Paris: European Association of Urology. 5 ed. 2013[cited 2015 Aug 18]. Available from: http://www.icud.info/PDFs/INCONTINENCE\%202013.pdf

13. NHSN [base de dados internet]. Urinary Tract Infection (UTI). Event for Long-term Care Facilities. 2012 [cited 2016 Nov 22]. Available from: https://www.cdc.gov/nhsn/PDFs/LTC/LTCF-UTI-protocol_FINAL_8-24-2012.pdf

14. Brasil. Ministério da Saúde. Resolução n 466 de dezembro de 2012. Comissão Nacional de Ética em Pesquisa. CONEP [Internet]. 2012 [cited 2016 Jan 12]. Available from: http://bvsms.saude.gov.br/bvs/saudelegis/cns/2013/res0466_12_12_2012.html.

15. Tamanini JTN, D'Ancora CAL, Palma PCR, Netto Jr NR. Validação para o português do "International Consultation on Incontinence Questionnaire - Short form" (ICIQ-SF). Rev Saude Publica [Internet]. 2004 [cited 2016 Mar 13];38(3):438-44. Available from: http://www.scielo.br/pdf/rsp/v38n3/20662.pdf

16. Mingoti SA. Métodos de amostragem com aplicações na área empresarial com o enfoque integrado ao software "sampling". Departamento de Estatística da UFMG. Universidade Federal de Minas Gerais: Belo Horizonte; 2000. $90 f$.

17. Azeredo Z, Matos E. Grau de dependência em doentes que sofreram AVC. Rev Fac Med Lisboa. 2003;8 (4):199-204.

18. Minosso JSM, Amendola F, Alvarenga MRM, Oliveira MAC. Validação, no Brasil, do Índice de Barthel em idosos atendidos em ambulatórios. Acta Paul Enferm [Internet]. 2010 [cited 2016 Sep 02];23(2):218-23. Available from: http://www.scielo.br/pdf/ape/ v23n2/11.pdf

19. Landis JR, Koch GG. The measurement of observer agreement for categorical data. Biommetrics [Internet]. 1977 [cited 2016 Mar 02];33(1):159-74. Available from: https://www.ncbi.nlm.nih.gov/pubmed/843571

20. Chen SL, Hung CS, Pinkner JS, Walker JN, Cusumano CK, Li Z, et al. Positive selection identifies an in vivo role for FimH during urinary tract infection in addition to mannose binding. Proc Natl Acad Sci USA [Internet]. 2009 [cited 2016 Nov 02];106(52):2243944. Available from: https://www.ncbi.nlm.nih.gov/pmc/articles/PMC2794649/pdf/zpq22439.pdf

21. Rowe TA, Juthani-Mehta M. Diagnosis and management of urinary tract infection in older adults. Infect Dis Clin North Am [Internet]. 2014 [cited 2016 Sep 14];28(1):75-89. Available from: https://www.ncbi.nlm.nih.gov/pmc/articles/PMC4079031/.

22. Van Bull LW, Veenhuizen RB, Achterbeg WP, Schellevis FG, Essink RTGM, Greeff SC, et al. Antibiotic prescribing in dutch nursing homes: how appropriate is it? J Am Med Dir Assoc [Internet]. 2015 [cited 2016 Feb 18];16(3):229-37. Available from: http://www. jamda.com/article/S1525-8610(14)00621-5/pdf

23. Ariathianto Y. Asymptomatic bacteriuria: prevalence in the elderly population. Aust Fam Physician [Internet]. 2011 [cited 2016 Jan 15];40(10):805-9. Available from: http://www.racgp.org.au/afp/201110/44367

24. COREN-SP. Conselho Regional de Enfermagem. São Paulo. Dimensionamento de Pessoal [Internet]. São Paulo. 2010 [cited 12 Jan 2016]. Available from: http://www.portalcoren-rs.gov.br/docs/Dimensionamento/livreto_de_dimensionamento.pdf

25. Brasil. Agência Nacional de Vigilância Sanitária (ANVISA). Portaria n 41 de 18 de janeiro de 2004. Consulta Pública. Diário Oficial da União. 21 de junho de 2004.

26. Marques LVP, Carvalho DV. Sistematização da assistência de enfermagem em cento de tratamento intensivo: percepção das enfermeiras. REME [Internet]. 2005 [cited 2016 Aug 30];9(3)199-205. Available from: http://www.reme.org.br/artigo/detalhes/461

27. Tannure MC, Pinheiro AM. Sistematização da Assistência de Enfermagem: Guia Prático. 2 ed. Rio de Janeiro: Guanabara Koogan; 2011. 